\title{
Aspectos socioeconômicos relacionados à parasitoses em pré-escolares
}

\author{
Mariane Roberta da Silva, Mariana Costa Fausto, Eliangela Saraiva Oliveira Pinto, Guilherme \\ Costa Fausto, Rogério Pinto
}

\begin{abstract}
Resumo
As parasitoses intestinais representam-se como um grave problema de saúde pública no Brasil. Essas doenças estão relacionadas à más condições higiênicas sanitárias, atingindo principalmente crianças menores de cinco anos, devido a seus hábitos de higiene precários e sua imunidade ainda em desenvolvimento, podendo causar graves complicações físicas e cognitivas. Avaliar os aspectos socioeconômicos e culturais e identificar principais fatores de risco para a ocorrência de parasitoses intestinais em crianças. Realizou-se uma pesquisa com crianças em uma creche municipal situada no município de Viçosa-MG. A coleta de dados se deu por meio da aplicação de um questionário estruturado aos pais das crianças. Verificou-se que $48,27 \%$ dos pais possuem renda familiar igual a dois salários mínimos e que $41,37 \%$ convive com 4 pessoas na família. Além disso, 41,37\% possuem animais em casa, $24,13 \%$ possuem horta e 3,70\% dos participantes relatam não utilizar agua filtrada para o consumo. Em relação aos hábitos alimentares, 77,77\% disseram comer verduras cruas e $89,65 \%$ não comem carne crua ou mal passada. Quanto ao hábito de andar descalços $44,82 \%$ dos pais afirmaram que as crianças sempre o faziam. Para os hábitos de higiene pessoal das crianças, verificou-se que apenas 17,24\% lavam as mãos das crianças antes das refeições. Quanto ao controle preventivo de verminoses da família, $65,51 \%$ dos entrevistados não possuem o hábito de fazer o controle preventivo. Em relação ao tratamento de verminoses entre as crianças, 72,41\% afirmaram que nunca fizeram um tratamento para verminoses e dentre as $27,58 \%$ das crianças que fizeram algum tratamento, $42,85 \% \mathrm{o}-\mathrm{fez}$ a mais de um ano. Conclui-se que os fatores de risco para a ocorrência de verminoses, nas famílias das crianças participantes da pesquisa, foi a presença de animais em residência, a deficiência no controle preventivo das verminoses nas crianças, a higiene das mãos inadequadas antes das refeições e o risco direto das crianças por conviverem em ambiente coletivo.
\end{abstract}

Descritores: Criança; Saúde Pública; Verminose. 